\title{
Fecal nitrogen of the white-tailed deer (Odocoileus virginianus) in
} southern México

\section{Nitrógeno fecal del venado cola blanca (Odocoileus virginianus) en el sureste de México}

\author{
Ermilo Humberto López-Cobá ${ }^{1 *}$, Candita Mariana Euán-Canul ${ }^{2}$, Rubén Cornelio Montes-Pérez ${ }^{3}$, and Jorge Rodolfo Canul-Solís ${ }^{1}$ \\ 'Tecnológico Nacional de México/Instituto Tecnológico de Tizimín, División de Estudios de Posgrado e Investigación. Final Aero- \\ puerto Cupul s/n, CP. 97700, Tizimín, Yucatán, México. Email: ermilo.lopez@ittizimin.edu.mx (EHL-C), jorge.canul@ittizimin.edu.mx \\ (JRC-S). \\ 2Universidad Autónoma de Yucatán, Campus de Ciencias Biológicas y Agropecuarias. Laboratorio de Recursos Florísticos de Meso- \\ américa. Km 15.5 Carretera Mérida-Xmatkuil, CP. 97315, Mérida, Yucatán. México. Email: candita.euan@correo.uady.mx (CME-C). \\ ${ }^{3}$ Universidad Autónoma de Yucatán, Campus de Ciencias Biológicas y Agropecuarias. Departamento de Reproducción. Km 15.5 \\ Carretera Mérida-Xmatkuil, CP. 97315, Mérida, Yucatán México. Email: mperez@correo.uady.mx (RCM-P). \\ ${ }^{*}$ Corresponding author
}

\begin{abstract}
The seasonal changes of the plant species consumed by the white-tailed deer in wildlife influence the availability and quality of their diet and is directly proportional to fecal nitrogen (FN). The objective is to evaluate the content of FN and the use of the fragmented habitat of the white-tailed deer in the dry season when food is scarce. We installed 300 quadrants of $100 \mathrm{~m}^{2}$ in different habitat types: agricultural, secondary vegetation, and tropical forest in the drought season of 2011. Twenty-seven samples of fresh feces were selected and the FN was quantified to relate it to the quality of food in the habitat fragments. The use of habitat fragments was determined by the distribution of tracks and feces recorded in the quadrants. The levels of FN were of $2.495 \pm 0.580 \mathrm{mg} / \mathrm{ml}$ without significant differences between habitat fragments $(P>0.05)$. In the use of habitat fragment there was no significant difference $(P>0.05)$. Deer ingest foods that contain a relatively high amount of protein, regardless of habitat type, and they use habitat fragments to consume quality foods based on seasonal availability.
\end{abstract}

Key words: Feeding; foraging; habitat; quality; seasonality.

Los cambios estacionales de las especies vegetales consumidas por el venado cola blanca (Odocoileus virginianus) en vida silvestre influyen en la disponibilidad y calidad de su dieta y son proporcionales al nitrógeno fecal (NF). El objetivo del presente trabajo fue evaluar el contenido de NF y el uso del hábitat del venado cola blanca en la estación seca cuando el alimento es escaso. Se establecieron 300 cuadrantes de 100 $\mathrm{m}^{2}$, en fragmentos de habitat agrícola, vegetación secundaria y selva en la estación seca de 2011 . Se seleccionaron 27 excretas frescas y se cuantificó el NF, para relacionarlo con la calidad de la alimentación en los fragmentos del hábitat. El uso del hábitat se determinó por la distribución de huellas y excretas registradas en los cuadrantes. Los niveles de FN fueron de $2.495 \pm 0.580 \mathrm{mg} / \mathrm{ml}$ sin diferencias significativas entre los fragmentos de hábitat $(P>0.05)$. En el uso de hábitat no hubo diferencias significativas $(P>0.05)$. Los venados ingieren alimentos que contienen una cantidad relativamente alta de proteínas, independientemente del tipo de hábitat, y también usan los fragmentos de hábitat para consumir alimentos de calidad de acuerdo con la disponibilidad estacional.

Palabras clave: Alimentación; calidad; forrajeo; hábitat; temporalidad.

(C) 2020 Asociación Mexicana de Mastozoología, www.mastozoologiamexicana.org

The behavior of herbivory, habitat use and reproductive success in wildlife of the white-tailed deer (WTD), Odocoileus virginianus is usually linked to the quality and quantity of food ingested. An indirect method to measure this quality is the fecal nitrogen index (FN). This method is relatively inexpensive and it is not necessary to capture specimens from the study population, the samples that are collected are feces, therefore this type of sample, also, it serves to carry out population studies (Mandujano 2014; Monteith et al. 2014; Gallina et al. 2015).

Several studies have shown a strong correlation between FN and diet quality attributes, including intake, digestibility, changes in weight and phosphorus in the diet of several of cervids such as Cervus elaphus, O. hemionus and C. nippon (Holechek et al. 1982; Leslie and Starkey 1985; Howery 1987; Osborn and Ginnet 2001; Ueno et al. 2007). In WTD, relationships between FN and organic nitrogen have been established in the plants it consumes (Howery and Pfister 1990), reproductive status (Monteith et al. 2014) and sexual segregation (Gallina et al. 2015).

The FN is usually influenced by the quality of the diet, regardless of the physiological state of the animal. In addition, the seasonal changes in the plant species consumed by the WTD, and which are available in the habitats, influence the availability and digestibility of the forage (Leslie and Starkey 1985; Duncan and Gordon 1999). Brown et al. (1995) demonstrated that low levels of FN were associated with low levels of protein and energy in the diet of the deer. Other studies have linked high levels of FN with high levels of tannins rather than high levels of nitrogen in the diet or high digestibility rates, finding that the FN is frequently high and variable in herbivores that consume shrubs and herbaceous species (Howery 1987; Thompson 1987; Osborn and Ginnet 2001). However, the saliva 
in members of the genus Odocoileus, like other deer of the concentrate selector type, contains substances that bind to tannins, neutralizing them for the most part, thereby managing to digest the proteins in the food more efficiently (Austin et al. 1989; Hofmann 1999).

The type of vegetation, its distribution and abundance are proportionally linked to rainfall (Granados et al. 2014). The sub-humid warm climate of Yucatán is characterized by two seasons determined mainly by rainfall: rainy season (from June to November) and dry season (from December to May), so in the dry season there is little availability of plants consumed by the WTD (Mardero et al. 2012). Our hypothesis is that, due to the lower rainfall during the dry season in Yucatán, the quality and abundance of vegetation are affected negatively, and therefore expecting in low FN levels. The habitat also influences the consumption behavior of WTD, using areas with greater food availability, such as agriculture fields and secondary vegetation. This study aims to evaluate the content of FN and the use of habitat fragments of the WTD during the dry season, in Yucatán state, México.

The study was conducted in Tzucacab, municipality of Yucatán, México, located between $19^{\circ} 38^{\prime \prime}$ and $20^{\circ} 09^{\prime \prime} \mathrm{N}$ and $88^{\circ} 59^{\prime \prime}$ and $89^{\circ} 14^{\prime \prime} \mathrm{W}$, and with $1,289 \mathrm{~km}^{2}$ of which $302.16 \mathrm{~km}^{2}$ corresponding of native vegetation (Wyman et al. 2007). The climate is Aw1 ( $\left.\mathrm{i}^{\prime}\right) \mathrm{g}$, corresponding to the warm sub-humid with mostly summer rains, which has little thermal oscillation (Duch 1988). The soil can be Lithosol or Luvisol types, having mainly bare rocks, with an average depth of $10 \mathrm{~cm}$, although in some parts they can reach 60 $\mathrm{cm}$. The vegetation cover or natural habitat corresponds to the type of tropical medium subdeciduous forest, the habitat is fragmented, especially for secondary vegetation with different successional stages, agricultural and livestock systems (Wyman et al. 2007). From March to May (dry season) six transects of 5,000 m long and $2 \mathrm{~m}$ wide, were installed randomly located in the municipality of Tzucacab (Figure 1).

Three hundred square plots of $100 \mathrm{~m}^{2}(10 \times 10 \mathrm{~m})$ were installed, along these six transects, and the type of habitat was identified in each plot. The number of tracks and feces was recorded in each type of fragment. The chi-square test (Byers et al. 1984) was used to test the use of each fragment or habitat type according to them disponibility. The expected number of observations in each habitat type was computed by multiplying the relative area of the habitat type by the total number of tracks registered. With these data the chisquare goodness-of-fit test $\left(X^{2}=\Sigma\left(O_{i}-E_{i}\right)^{2} / E_{i}\right)$ was realized.

A single deposition of 10 or more pellets was considered as a fecal group, with equal characteristics of coloration, size, and humidity (Elbroch 2003). Fecal groups that showed to be fresh were selected, because of its brightness and humidity; the dried ones, with fungi or insect larvae were discarded. The pellets were collected in the apical part of the fecal cluster to avoid contamination by soil and litter remains; they were placed in paper bags and transferred to the laboratory. The samples were dried at $60{ }^{\circ} \mathrm{C}$ for $48 \mathrm{~h}$ and then ground, as finely as possible, with a conventional

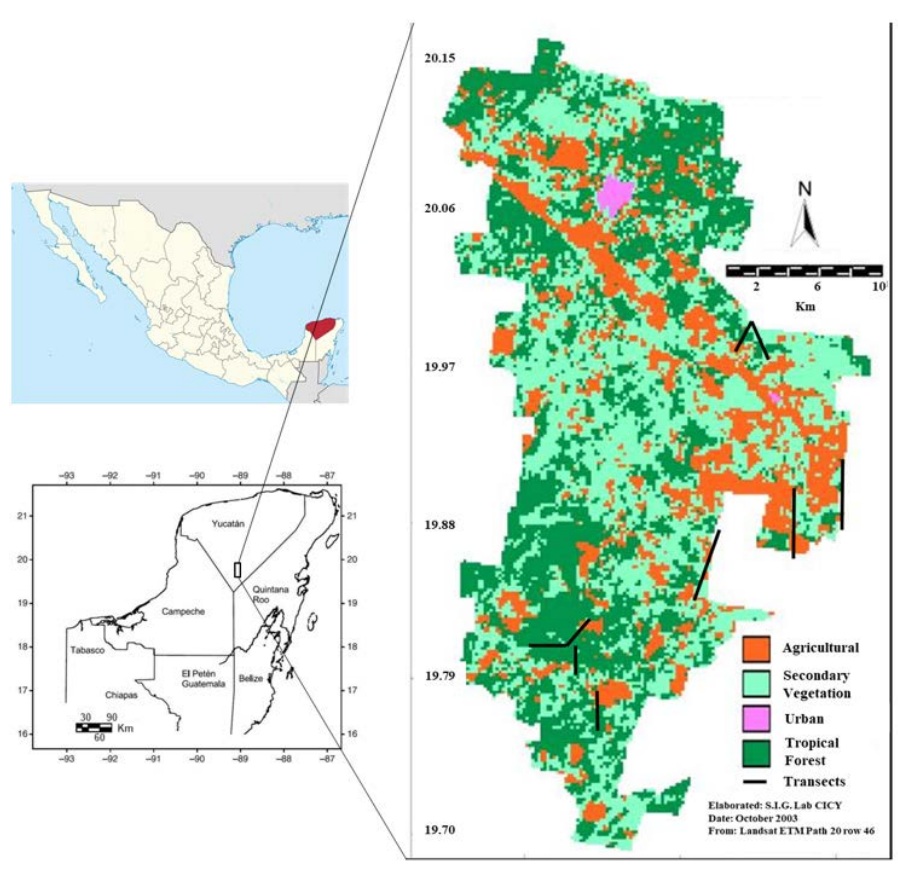

Figure 1. Study area in the municipality of Tzucacab, Yucatán, México.

blender (Moulinex, model 4090). The fecal groups were separated according to the habitat type where they were collected: secondary vegetation (SV), agricultural (AG), and tropical forest $(\mathrm{T})$.

To contrast the food quality with that of animals in captivity, six samples were obtained in the Wildlife Management Unit (WMU) "Xmatkuil" of the Campus of Biological and Agricultural Sciences of the Autonomous University of Yucatán, located in Mérida, Yucatán. These animals have ad libitum diet based on fruits (papaya, cucumber and pumpkin), tree fodder (Brosimum alicastrum and Leucaena leucocephala), and supplemented with commercial feed for pigs, with crude protein contents of $9 \%$.

The FN content of each sample was quantified in duplicate by the Kjeldahl method (AOAC 1999) and expressed as a percentage of dry matter using a micro-Kjeldahl device, (VELP Scientifics brand, model DK-6). To find differences in the contents of FN, the non-parametric Kruskal-Wallis test was performed because it did not meet the normality requirements.

The plots in each habitat were distributed as follows: SV: 46, AG: 103 and T: 151. In these we found 6, 24 and 58 tracks in SV, AG and T, respectively (Table 1). No significant differences $\left(P>0.05, X^{2}=5.616, \mathrm{df}=2\right)$ were found in the use of habitat type by the WTD. One hundred fifty-three total tracks were obtained and 65 samples of fecal groups of whitetailed deer, 27 of which were taken as suitable for measuring FN. The fecal samples for the NF analysis were classified as follows: SV: 4, AG: 2, T: 21. The FN in each type of habitat (average \pm standard deviation) was: $\mathrm{SV}=2.198 \pm 0.577 \mathrm{mg} /$ $\mathrm{ml}, \mathrm{AG}=2.574 \pm 0.436 \mathrm{mg} / \mathrm{ml}$ and $\mathrm{T}=2.543 \pm 0.597 \mathrm{mg} / \mathrm{ml}$ and globally of $2,495 \pm 0.580 \mathrm{mg} / \mathrm{ml}$. The concentrations of FN did not have significant differences according to habitat type $(P>0.05)$. For the samples obtained in the WMU, the FN was $2,535 \pm 0.695$. There were no significant differences between wild habitats and the WMU $(P>0.05)$. 
Table 1. Data used for each fecal plots by habitat type in Tzucacab, Yucatán, México.

\begin{tabular}{lcccc} 
Habitat & $\begin{array}{c}\text { Number } \\
\text { plots }\end{array}$ & $\begin{array}{c}\text { Relative } \\
\text { plots }\end{array}$ & $\begin{array}{c}\text { Expected } \\
\text { usage } \\
\text { (Ei) }\end{array}$ & $\begin{array}{c}\text { Observed } \\
\text { usage } \\
\text { (Oi) }\end{array}$ \\
\hline Tropical forest (T) & 151 & 0.50 & 44.3 & 58 \\
Secondary vegetation (SV) & 46 & 0.15 & 13.5 & 6 \\
Agricultural (AG) & 103 & 0.34 & 30.2 & 24 \\
\hline
\end{tabular}

The wild NF values obtained show a high-quality diet since they are similar to those recorded in captive animals in the WMU with diets supplemented with $9 \%$ protein already found by Howery and Pfister (1990) when they are provided with high levels of protein (foods with $16.5 \%$ crude protein, with a value of $2.26 \mathrm{mg} / \mathrm{ml}$ of FN) to females of WTD. Massey et al. (1994) reported low FN values (1.92 $\mathrm{mg} / \mathrm{ml}$ ) in black-tailed deer (O. hemionus columbianus) in the dry season when nutritious foods are scarce.

However, the highest levels of FN $(2.495 \mathrm{mg} / \mathrm{ml})$ obtained from the WTD in wildlife in this research confirm that due to the type of foraging, the deer is selective, ingesting foods that provide the nutrients it needs (Berteux et al. 1998; Silva-Villalobos et al. 1999; Dostaler et al. 2011).

This food selection was also demonstrated by Granados et al. (2014) in a study of the WTD in the Yucatán Peninsula where they found that the plant species consumed in the dry season decreased ( 12 species against 29 in the rainy season) and that the most consumed species in the dry season was L. leucocephala, which has a crude protein content of 24.63 $\%$ dry matter (DM), a high digestibility rate ( $81 \% \mathrm{DM})$ and a low tannin content (2.09\% DM; López-Cobá et al. 2007). This behavior of maximizing the consumption of high-quality foods and minimizing that of secondary metabolites has been mentioned by Duncan and Gordon (1999).

Although they have been reported that agricultural areas in the dry season can serve as feeding areas to the WTD, due to the availability of sprouts (Mandujano and Rico-Gray 1991; Greenberg 1992; Meek et al. 2008), which are more palatable and $20-30 \%$ richer in organic nitrogen (Robbins et al. 1975). However, the use for some type of habitat can also be explained by the WTD's foraging strategy, typical of an opportunistic concentrate selector to feed in addition to woody material (Granados et al. 2014), such as those found in shrubs, stems and tropical leaves and secondary vegetation. These last sites can also provide them with shade and rest sites, an important factor in hot weather, since it has been observed that herbivores at this time increase their body temperature, heart rate, and respiration rate, affecting their voluntary consumption by reducing their foraging time while remaining in the shade and increasing inactivity (Morillo 1994). These foraging strategies, applied by these herbivores, allow them to ingest high-quality food, even if it is to a lesser extent, given the limited availability (Duncan and Gordon 1999).

\section{Acknowledgements}

To the National Council of Science and Technology (CONACYT) of México through the program of Mixed Funds CONACYT and the Government of the State of Yucatán with the project YUC-2006-C05-65725 for financing this project. To the staff of Campus of Biological and Agricultural Sciences of the Autonomous University of Yucatán for the facilities granted in the Teaching Laboratory. To the administrators and workers of the WMU "Xmatkuil" for their collaboration in the implementation of this research. To the editor and reviewers for their comments that enriched the work.

\section{Literature cited}

Association of Official Analytical Chemist (AOAC). 1999. Official Methods of Analysis. Association of Official Analytical Chemists. Washington, D. C., U.S.A.

Austin, J. P., L. Suchar, C. Robbins, and A. Hagerman. 1989. Tannin binding in saliva deer and their absence in saliva of sheep and cattle. Journal of Chemistry Ecology 15:1335-1347.

Berteux, D., M. Crête, J. Huot, J. Maltais, and J. Ouellet. 1998. Food choice by white-tailed deer in relation to protein and energy content of the diet: a field experiment. Oecologia 115:84-92.

Brown, R., E. Hellgren, M. Авott, D. Ruthven, and R. Bingham. 1995. Effects of dietary energy and protein restriction on nutritional indices of female white-tailed deer. The Journal of Wildlife Management 59:595-609.

Byers, C. R., R. Steinhorst, and P. Krausman. 1984. Clarification of a technique for analysis of utilization-availability data. Journal of Wildlife Management 48:1050-1053.

Dostaler, S., J. Ouellet, J. Therrien, and S. Côte. 2011. Are feeding preferences of white-tailed deer related to plant constituents? The Journal of Wildlife Management 75:913-918.

Duch, J. 1988. Conformación territorial del estado de Yucatán. Universidad Autónoma Chapingo. Estado de México, México.

Duncan, A., AND I. GoRDon. 1999. Habitat selection according to the ability of animals to eat, digest and detoxify foods. Proceedings of the Nutrition Society 58:799-805.

ELBRoCH, M. 2003. Mammal Tracks \& Sign: A Guide to North American Species. Stackpole Books. Pennsylvania, U.S.A.

Gallina, S., G. Sánchez-Rojas, A. Buenrostro-Silva, and C. A. LóPEZ-GonzÁLez. 2015. Comparison of fecal nitrogen concentration between sexes of white-tailed deer in a tropical dry forest in southern Mexico. Ethology Ecology and Evolution 27:103-115.

Granados, D., L. Tarango, G. Olmos, J. Palacio, F. Clemente, and G. Mendoza. 2014. Dieta y disponibilidad de forraje del venado cola blanca Odocoileus virginianus thomasi (Artiodactyla: (ervidae) en un campo experimental en Campeche. México. Revista de Biología Tropical 62:699-710.

GreenberG, L. S. 1992. Garden hunting among the Yucatecan Maya: a coevolutionary history of wildlife and culture. Etnoecológica 1:23-33.

Hofmann, R. R. 1999. Experimental evidence for morphologically predicted adaptations in selectively feeding cervids. Pp. 208-211 in Advances in Deer Biology (Zomborszky, Z., ed.). Proceedings of the 4th International Deer 
Biology Congress. Pannon University of Agriculture. Kaposvar, Hungary.

Holechek, J. L., M. Vavra, ANd R. D. Pieper. 1982. Methods for determining the nutritive quality of range ruminant diets: a review. Journal of Animal Science 54:363-376.

Howery, L. 1987. Fecal indices to predict diet quality and reproductive status of wild ungulates. Thesis of Master of Sciences. Texas Tech University. Texas, U.S.A.

Howery, L., AND J. Pfister. 1990. Dietary and fecal concentrations of nitrogen and phosphorus in penned white-tailed deer does. Journal of Wildlife Management 54:383-389.

Leslie, D. M., ANd E. E. Starkey. 1985. Fecal indices to dietary quality of cervids in old-growth forests. Journal of Wildlife Management 49:142-146.

López-Cobá, E., C. Sandoval-Castro, and R. Montes-Pérez. 2007. Intake and digestibility of tree fodders by Whitetailed deer (Odocoileus virginianus yucatanensis). Journal of Animal and Veterinary Advances 6:39-41.

Massey, B., F. Weckerly, C. Vaughn, And D. McCullough. 1994. Correlations between fecal nitrogen and dietary composition in free-ranging black-tailed deer. The Southwestern Naturalist 39:165-170.

Mandujano, S. 2014. Variación del nitrógeno fecal de Odocoileus virginianus a diferentes tiempos de exposición ambiental. Therya 5:831-838.

Mandujano, S., And V. Rico-Gray. 1991. Hunting, use and knowledge of the biology of the white-tailed deer (Odocoileus virginianus Hay) by the Maya of central Yucatan, Mexico. Journal of Ethnobiology 11:175-183.

Mardero, S., E. Nickl, B. Schmook, L. Scheneider, J. Rogan, Z. Christman, and D. Lawrence. 2012. Sequías en el sur de la península de Yucatán: análisis de la variabilidad annual y estacional de la precipitación. Investigaciones Geográficas, Boletín del Instituto de Geografía 78:19-33.

Meek, M., S. Cooper, M. Owens, R. Cooper, And A. WAppel. 2008. White-tailed deer distribution in response to patch burning rangeland. Journal of Arid Enviroments 72:2026-2033.

Monteith, K.B., K.L. Monteith, R.T. Bowyer, D.M. Leisle, AND J.A. JENKs. 2014. Reproductive effects on fecal nitrogen as an index of diet quality: an experimental assessment. Journal of Mammalogy 95:301-310.

Morillo, E. 1994. Efectos de la época seca sobre la producción forrajera y bovina. Revista de Agronomía (LUZ) 11:152-163.

Osborn, R. G., And T. F. Ginnett. 2001. Fecal nitrogen and 2,6-diaminopimelic acid as indices to dietary nitrogen in white-tailed deer. Wildlife Society Bulletin 29:1131-1139.

Robbins, C., P. Van Soest, W. Mautz, and A. Moen. 1975. Feed analyses and digestion with reference to white-tailed deer. The Journal of Wildlife Management 39:67-79.

Silva-Villalobos, G., S. Mandujano, G. Arceo, S. Gallina, and L. Pérez-Jiménez. 1999. Nutritional characteristics of plants consumed by the white-tailed deer in a tropical forest of Mexico. Vida Silvestre Neotropical 8:38-42.

Thompson, N. 1987. Fecal indices to dietary quality: a critique. Journal of Wildlife Management 51:317-320.

Ueno, M., C. Nishimura, H. Takahashi, K. Kaul, and T. Saito. 2007. Fecal nitrogen as an index of dietary nitrogen in two sika deer Cervus nippon populations. Acta Theriologica 52:119-128.
Wyman, M., Z. Gómez-Villegas, And I. Miranda-OJeda. 2007. Land-use/land-cover change in Yucatan State, Mexico: an examination of political, socioeconomic, and biophysical drivers in Peto and Tzucacab. Ethnobotany Research and Applications 5:56-77.

Associated editor: José F. Moreira-Ramírez

Submitted: April 18, 2020; Reviewed: June 2, 2020.

Accepted: June 6, 2020; Published on line: June 16, 2020. 